\title{
SUMBANGAN NON TUNAI PADA PEMBANGUNAN MASJID BAITURRAHIM KAB. PINRANG DALAM HUKUM ISLAM
}

\author{
Umaima, Hariyanto, Rusnaena \\ IAIN Parepare ${ }^{1}$, IAIN Parepare ${ }^{2}$, IAIN Parepare ${ }^{3}$ \\ umaima@iainpare.ac.id ${ }^{1}$, hariyanto_irex@gmail.com², rusnaena@iainpare.ac.id ${ }^{3}$
}

\begin{abstract}
The community of Sempang hamlet Patampanua Pinrang Regency made a backthrought of making transaction to collecting donations from residents of mosque. This contributions are non cash or goods but only recognition of contract. This research was conducted by normative phenomenological and theological approach to analize the concept about non-cash donation contract and how the law of non-cash donation in islamic law. As the result of this research; the law of non-cash donations is basically permissible if that is not contain elements of force and showing off
\end{abstract}

Kata Kunci: Non Cash Donation, Contract, Transaction, Debt

\begin{abstract}
Abstrak
Masyarakat Dusun Sempang Kecamatan Patampanua Kabupaten Pinrang melakukan suatu terobosan bertransaksi dalam memungut sumbangan pembangunan masjid dari para warga. Sumbangan tersebut sifatnya non tunai, bukan dalam wujud uang maupun barang namun hanya berupa pengakuan dalam akad. Penelitian ini dilakukan dengan pendekatan fenomenologi dan teologis normatif dalam mengkaji konsep akad sumbangan non tunai dan bagaimana hukum sumbangan tersebut dalam fiqhi ekonomi. Adapun hasil penelitian ini secara umum adalah hukum sumbangan non tunai pada dasarnya adalah boleh dengan catatan tidak mengandung unsur paksaan dan riya.
\end{abstract}

Keyword: Sumbangan Non Tunai, Akad, Transaksi, Utang

\section{Pendahuluan}

Manusia memiliki kebutuhan yang sangat beragam, sehingga terkadang secara pribadi mereka tidak mampu untuk memenuhinya, dan mau tidak mau harus berkomunikasi dengan orang lain. Hubungan ini merupakan fitrah yang sudah ditakdirkan dan Islam sebagai agama yang komprehensif dan universal telah memberikan aturan yang cukup jelas untuk dapat diimplementasikan oleh manusia seiring perkembangan masa. Hubungan antara satu manusia dengan manusia lain dalam memenuhi kebutuhan, di dalamnya memang harus terdapat aturan yang menjelaskan hak dan kewajiban keduanya berdasarkan kesepakatan. Proses untuk membuat kesepakatan dalam kerangka memenuhi kebutuhan keduanya, lazim disebut dengan proses berakad atau melakukan kontrak.

Akad, kontrak atau perjanjian/ perikatan antara dua pihak atau lebih, dibahas secara rinci dalam lingkup fiqhi muamalah. Menurut Muhammad Kamal Zubair, keberadaan akad memiliki peranan yang krusial dalam lapangan muamalah dan menimbulkan banyak implikasi. Islam memberikan kebebasan untuk melakukan akad asalkan akad tersebut dilakukan secara sukarela oleh pihak-pihak yang berakad dan tidak melanggar syariat. ${ }^{1}$ Akad yang dilakukan

1 Muhammad Kamal Zubair and Abdul Hamid, 'Eksistensi Akad Dalam Transaksi

\section{5 | B a l a n c a}

Jurnal Ekonomi dan Bisnis Islam

Volume 2 Nomor 1, Januari - Juni 2020 (15 - 23) 
dalam bertransaksi sangatlah beragam, sesuai dengan karakteristik dan spesifikasi kebutuhan para pelaku akad/ pihak-pihak yang berakad. Selain itu, di dalam akad juga harus jelas segala ketentuan berikut konsekuensi yang akan menjadi aturan main dalam proses transaksi.

Prosesi akad yang selama ini terjadi di tengah masyarakat biasanya hanya berkisar pada bidang muamalah, seperti akad transaksi, akad perwakilan (wakalah), akad utang-piutang (al-Qardh), dan pada bidang munakahat dimana kedua mempelai harus menjalani akad nikah. Namun berbeda halnya dengan sebuah kasus (case) yang terjadi di Dusun Sempang Kecamatan Patampanua Kabupaten Pinrang. Masyarakat setempat melakukan suatu terobosan bertransaksi dalam memungut sumbangan pembangunan masjid dari para warga. Panitia pembangunan masjid beserta pengurus masjid memanfaatkan waktu ramadhan untuk meminta kesediaan masyarakat untuk menyumbang demi pembangunan masjid dusun. Hal tersebut disambut hangat oleh warga demi kelancaran pembangunan. Warga yang mayoritas petani kebanyakan belum sanggup memberikan sumbangan. Mereka hanya menyatakan kesediaan untuk menyumbang setelah tiba masa panen. Kesediaan warga petani untuk menyumbang tersebut harus disertai dengan menyebutkan nominal jumlah yang ingin disumbangkan. Hal tersebut panitia lakukan agar dapat mengkalkulasi kemungkinan biaya pembangunan masjid dan dengan adanya akad yang berupa pernyataan kesediaan untuk menyumbang maka akan mempermudah pembangunan.

Transaksi berakad tersebut memunculkan sumbangan yang sifatnya non-tunai/ utang. Sumbangan yang sudah ditentukan nominal atau jumlahnya, baik berupa uang maupun barang namun belum nampak wujudnya. Hal yang membuat penulis merasa gelisah adalah

Keuangan Syariah', Diktum: Jurnal Syariah Dan Hukum, 14.1 (2016), 44-54. bahwa sumbangan pada umumnya bersifat tunai, baik berupa uang maupun barang. Semua tergantung keinginan dan keikhlasan si penyumbang, tanpa ada paksaan atau sesuatu hal lain yang mendorong kecuali mengharap rahmat dan ridha Allah swt semata. Berdasarkan hal tersebut, penelitian ini akan membahas tentang bagaimana prosesi terjadinya akad pemungutan sumbangan pembangunan Masjid Baiturrahim Pinrang dan bagaimana hukumnya dalam Islam.

\section{Landasan Teori}

Penelitian ini akan menggunakan suatu bangunan kerangka teoretis atau konsepkonsep yang menjadi grand teori dalam menganalisis permasalahan yang akan diteliti atau untuk menjawab permasalahan penelitian yang telah dibangun sebelumnya. Adapun konsep dasar yang digunakan adalah:

\section{Konsep Akad dalam Fiqh}

Akad adalah suatu macam tasarruf yang dilakukan manusia. Tasarruf menurut ilmu fiqh adalah:

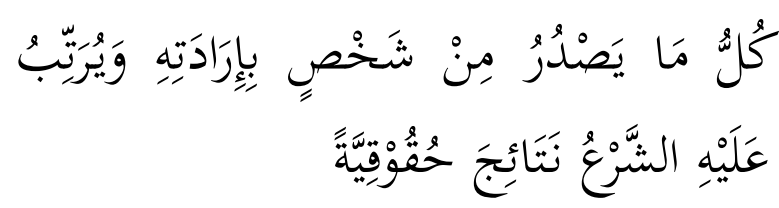

"Segala yang dilakukan seseorang dengan kehendaknya dan syara' menetapkan kepada orang tersebut beberapa haknya."2

Akad atau kontrak berasal dari bahasa Arab yang berarti ikatan atau simpulan baik ikatan yang nampak (hissiy) maupun tidak nampak (ma'nawiy). ${ }^{3}$ Kamus al-Mawrid, menterjemahkan al-'Aqd sebagai contract and

${ }^{2}$ Tengku Muhammad Hasbi AshShiddieqy, Pengantar Figh Muamalah (Cet. III, Semarang: Pustaka Rizki Putra, 2009), 22-23.

${ }^{3}$ Fayruz Abadyy Majd al-Din Muhammad Ibn Ya'qub, al-Qamus al-Mubit, Jilid 1 (Beirut: D Jayl, t.th.), 327

\section{5 | B a l a n c a}


agreement atau kontrak dan perjanjian. ${ }^{4}$ Sedangkan akad atau kontrak menurut istilah adalah suatu kesepakatan atau komitmen bersama baik lisan, isyarat, maupun tulisan antara dua pihak atau lebih yang memiliki implikasi hukum yang mengikat untuk melaksanakannya. ${ }^{5}$ Terdapat juga pakar yang mendefinisikan al-'aqd sebagai satu perbuatan yang sengaja dibuat oleh dua orang berdasarkan kesepakatan atau kerelaan bersama.

Dalam hukum Islam, istilah kontrak tidak dibedakan dengan perjanjian. Keduanya identik dan disebut akad. Sehingga dalam hal ini akad didefinisikan sebagai pertemuan ijab yang dinyatakan oleh salah satu pihak dengan kabul dari pihak lain secara sah menurut syarat yang tampak akibat hukumnya pada obyeknya. Dari beberapa pengertian di atas dapat diambil kesimpulan bahwa kontrak merupakan kesepakatan bersama baik lisan, isyarat, maupun tulisan antara dua pihak atau lebih melalui ijab dan qabul yang memiliki ikatan hukum bagi semua pihak yang terlibat untuk melaksanakan apa yang menjadi kesepakatan tersebut.

Tata aturan dalam berkontrak sebenarnya jelas diajarkan oleh nash-nash al-Qur'an, alHadis dan terdapat pula dalam kaidah-kaidah fiqhiyah. Islam telah memberikan petunjuk kepada setiap umat-Nya dengan peraturanperaturan yang terkandung di dalamnya, dalam transaksi hutang piutang akad sangatlah penting sehingga memunculkan adanya komitmen tertentu, sehingga semakin jelas rincian dan kecermatan dalam membuat akad, semakin kecil kemungkinan adanya konflik dan pertentangan kedua belah pihak (kreditur dan debitur dan haruslah mempunyai rasa tanggung jawab untuk

${ }^{4}$ Munir al-Ba'labakiyy, Qamus al-Mawrid (Beirut: Dar al-'Ilm al-Malayyin, 1990), 770.

${ }^{5}$ Muhammad Salam Madkur, al-Madkhal al-Fiqh al-Islamiyy (ttp: Dar al-Nahdah al'Arabiyyah, 1963), 506. memenuhinya. Dalam QS. al-Maidah ayat (1) Allah berfirman:

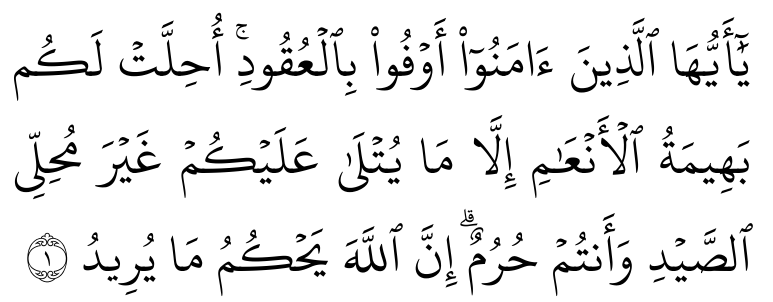

Terjemahnya:

"Hai orang-orang yang beriman, penuhilah akad-akad itu. Dihalalkan bagimu binatang ternak, kecuali yang akan dibacakan kepadamu. (Yang demikian itu) dengan tidak menghalalkan berburu ketika kamu sedang mengerjakan haji. Sesungguhnya Allah menetapkan hukum-hukum menurut yang dikehendaki-Nya."

Kata akad dalam ayat ini berbentuk jamak yang diberi alif- lam sehingga menjadikannya sebagai lafal umum. Jadi ayat ini mencakup segala macam akad baik yang timbal balik maupun yang sepihak dan semua syarat yang seseorang mengikatkan diri untuk melaksanakannya di masa depan. Setiap akad haruslah diiringi dengan rasa tanggung jawab, moral untuk saling memenuhi dan melaksanakannya dengan menanggung segala resiko yang akan muncul, sehingga tidak terjadi konflik antara kedua belah pihak.

\section{Sumbangan, Infaq dan Shadaqah}

Sumbangan secara umum adalah pungutan yang dilakukan oleh dan untuk kepentingan sekelompok masyarakat tertentu dan tidak memerlukan dasar hukum menurut undang-undang serta tidak mempunyai unsur paksaan, misalnya sumbangan pembangunan tempat-tempat ibadah, sumbangan perbaikan jalan dan lain-lain. Sedangkan dalam Islam, sumbangan diidentikkan dengan istilah shadaqah, infaq atau zakat. Namun dalam penelitian ini, penulis lebih condong kepada penggunaan kata infaq sebagai padanan kata sumbangan berdasarkan definisi dari terma masing-masing.

\section{6 | B a l a n c a}


Infaq" berarti pemberian (sumbangan) harta dan sebagainya untuk kebaikan. Secara istilah, infaq adalah segala macam bentuk pengeluaran (pembelanjaan) baik untuk kepentingan pribadi, keluarga, ataupun yang lain $^{6}$ atau mengeluarkan sebagian dari harta atau pendapatan/penghasilan untuk suatu kepentingan yang diperintahkan ajaran Islam. ${ }^{7}$ Menurut Mursyid dalam bukunya Mekanisme Pengumpulan Zakat, Infak dan Shadaqah (Menurut Hukum Syara' dan Undang-Undang), infaq merupakan asal dari kata nafaqa yang artinya menafkahkan atau membelanjakan. Bagi orang yang memberi keluarganya belanja, sama artinya dengan memberi nafkah, dan dalam hal memberikan belanjanya itu disebut menginfakkan. ${ }^{8}$

Berbeda halnya dengan persoalan zakat yang semuanya sudah tertera dengan jelas dan rapi dalam bab-bab fiqhi, mulai dari tentang siapa penerima atau pemberi, tentang berapa jumlah yang harus dizakatkan sampai kepada kapan waktu untuk mengeluarkan zakat tersebut. Zakat dan infaq adalah dua istilah yang biasa disepadankan dengan istilah sumbangan, namun keduanya merupakan dua hal yang berbeda. Zakat adalah kewajiban manusia untuk mendapatkan keselamatan sedangkan infak adalah keikhlasan manusia untuk mendapat rahmat dan ridha Allah swt. Proses berakad tersebut memunculkan sumbangan yang sifatnya non-tunai/ utang. Sumbangan yang sudah ditentukan nominal atau jumlahnya, baik berupa uang maupun barang namun belum nampak wujudnya. Hal yang membuat penulis merasa gelisah adalah

${ }^{6}$ Gus Arifin, Dalil-dalil dan Keutamaan Zakat, Infak, Sedekah (Jakarta: Elex Media Komputindo, 2011), 173.

${ }^{7}$ A. Zawawi Somad dkk. Ensiklopedi Islam (Jakarta: Anda Utama, 2003), 15.

${ }^{8}$ Mursyid, Mekanisme Pengumpulan Zakat Infaq dan Shadaqah Menurut Hukum Syara' dan UndangUndang) (Yogyakarta: Magistra Insania Press, 2006), 17. bahwa sumbangan pada umumnya bersifat tunai, baik berupa uang maupun barang. Semua tergantung keinginan dan keikhlasan si penyumbang, tanpa ada paksaan atau sesuatu hal lain yang mendorong kecuali mengharap rahmat dan ridha Allah swt semata

\section{Metode Penelitian}

Penelitian ini dilakukan dengan metode analisis data kualitatif yang didalamnya tidak menggunakan pengujian hipotesis melainkan pengkajian mendalam terhadap suatu objek secara alamiah. ${ }^{9}$ Penelitian ini juga dilakukan dengan menggunakan pendekatan fenomenologi dan teologis normatif yang bersifat perskriptif, ${ }^{10}$ yaitu penelitian yang bertujuan untuk menilai dan menggambarkan keadaan atau fenomena sosial, yang dalam hal ini adalah pendeskripsian pelaksanaan akad sumbangan yang berbentuk janji atau pengakuan pada pembangunan masjid di dusun Sempang Timur Kec. Patampanua Kab. Pinrang dan kemudian dianalisis dari sudut pandang fiqhi.

\section{Hasil Penelitian}

Proses Pemungutan Sumbangan Pembangunan Masjid Baiturrahim Kab. Pinrang

Masjid Baiturrahim yang berada di Dusun Sempang Timur dibangun dalam bentuk musalla pada tahun 1972 secara gotongroyong dan swadaya masyarakat. Selama beberapa tahun, masjid berdiri tanpa pondasi

9Andi Prastowo, Metode Penelitian Kualitatif dalam Perspektif Rancangan Penelitian (Yogyakarta: Ar-Ruzz Media, 2016), 24.

10Perskriptif merupakan suatu penelitian yang bertujuan untuk mendapatkan saran-saran mengenai apa yang harus dilakukan untuk mengatasi masalah tertentu. Soerjono Soekanto, Pengantar Penelitian Hukum (Jakarta: UI Press, 1986), 10. Dalam kamus Inggris-Indonesia mempunyai arti: memberikan petunjuk, ketentuanketentuan, bersifat menentukan. John M Echols dan Hassan Shadily, Kamus Inggris-Indonesia (cet. XXIII, Jakarta: Gramedia Pustaka, 1996), 444.

\section{7| B a l a n c a}


yang kokoh. Masyarakat kembali melakukan musyawarah dan membentuk pengurus pembangunan masjid yang baru. Dalam musyawarah tersebut, masyarakat juga mengusulkan agar dilakukan renovasi bahkan perombakan penuh pada bangunan masjid dikarenakan kondisi bangunan masjid lama yang sudah tua dan sudah tidak dapat menampung jamaah yang terlalu banyak lagi ketika bulan ramadhan tiba. Berdasarkan dari hasil musyawarah tersebut menghasilkan masjid dirubah total dengan masjid baru.

Berdasarkan kalkulasi dalam perencanaan, anggaran yang dibutuhkan lebih dari 1 milyar rupiah dan kemungkinan besar anggarannya membengkak disebabkan oleh tingkat harga bahan bakar minyak yang fluktuatif. Melihat hal itu, panitia pembangunan masjid bekerja ekstra agar masjid dapat segera terbangun. Pemungutan sumbangan yang dilakukan panitia pembangunan masjid menunggu hasil dari sumbangan bulan ramadhan. Masyarakat secara keseluruhan sebenarnya telah menyumbang namun jumlahnya hanya berkisar sepuluh juta rupiah. Hasil dari sumbangan masyarakat tersebut hanya mampu membangun pondasi dan tiang-tiang utama masjid, hingga pengurus masjid berinisiatif untuk melakukan pemungutan sumbangan (dengan cara yang mirip dengan pelelangan bahan-bahan bangunan) kepada masyarakat setiap hari jumat, sebelum khutbah jumat dimulai. Masyarakat merespon dengan baik dan menyepakati lelang (istilah yang digunakan masyarakat setempat) sumbangan baik berupa tunai (uang) maupun yang berbentuk bahan bangunan seperti semen, besi, pasir atau batu kerikil yang dapat dipergunakan untuk membangun hingga berhasil merampungkan seluruh pondasi dasar dan tiang inti bangunan masjid.

Pada bulan Ramadhan tahun 2013, panitia pembangunan masjid kembali melakukan pelelangan sumbangan. Pelelangan yang dimaksud adalah menawarkan kepada masyarakat yang menyanggupi untuk membeli bahan bangunan berupa semen, dll. dengan harapan dapat merampungkan lantai satu sehingga bisa ditempati dengan nyaman, dan akhirnya menyelesaikan semua dinding yang ada di lantai utama serta cor beton yang menyambungkan lantai satu dan dua bangunan tersebut.

Proses pelelangan sumbangan dari masyarakat yang dilakukan oleh panitia pembangunan masjid, ternyata tidak sesuai dengan harapan, dikarenakan $70 \%$ dari \pm 700 jumlah masyarakat dusun adalah petani mengeluh dengan mengatakan "Melo laddeki sah masumbang. Pakkuleang mi tammaddapi nasaba deppa namasangking taue. Duampulengpi yako dena saba',". ${ }^{11}$

Keluhan masyarakat tersebut membuat pengurus masjid berfikir dan akhirnya menanyakan langsung kepada tokoh masyarakat dan imam masjid perihal sistem pemungutan sumbangan dengan menggunakan metode pelelangan. Jawaban yang mereka dapatkan adalah hal tersebut boleh-boleh saja asalkan tidak memaksakan, tidak memberatkan dan hati-hati terhadap riya. Selama sesuatu dilakukan untuk kebaikan maka insya Allah akan baik juga hasilnya. Pada saat itu ada sebahagian masyarakat yang paham, tetapi ada juga yang tidak atau kurang jelas dalam memahaminya. Beberapa tokoh masyarakat berdialog langsung dan berakhir dengan kata sepakat bahwa masyarakat boleh menyumbang semen yang dapat dibayar setelah panen tiba (utang).

Beberapa masyarakat yang menyumbang menyampaikan langsung di saat panitia pembangunan mengumumkan hasil pemungutan sumbangan setiap malamnya di masjid. Namun kebanyakan masyarakat yang ingin menyumbang menyampaikan secara lisan maupun tulisan kepada pengurus

${ }^{11}$ Keinginan untuk menyumbang sangat besar namun waktu panen belum tiba masih butuh dua bulan hingga bulan panen tiba jika rejeki tidak ada yang menghalangi. 
pembangunan masjid untuk dicatatkan juga di dalam daftar penyumbang kontan maupun sumbangan berupa janji atau pengakuan. Di antara mereka juga ada yang meminta untuk dirahasiakan namanya dengan mendaftar sebagai "hamba Allah" atau "tanpa nama".

Sumbangan baik yang berupa tunai maupun yang berupa janji atau hanya pengakuan dicatat oleh panitia pembangunan masjid. Namun khusus pada pencatatan sumbangan non tunai tidak dilengkapi tanda tangan penyumbang, tanda persetujuan, atau jaminan untuk menguatkan kepastian si penyumbang. Menurut panitia pembangunan masjid, Bapak Sudirman yang pada saat itu adalah sekretaris pembangunan masjid bahwa janji atau pengakuan masyarakat seluruhnya sudah terbayarkan setelah masa panen tiba sesuai dengan jangka waktu yang ditentukan sendiri oleh si penyumbang. Dalam kurun waktu \pm dua bulan setelah bulan ramadhan, pada masa panen tiba $40 \%$ dari hasil pelelangan yaitu sumbangan yang berupa janji atau pengakuan ditunaikan oleh si penyumbang.

\section{Hukum Sumbangan Non Tunai dalam Fighi Ekonomi}

Mengenai ijab dan kabul dalam pelaksanaan akad sumbangan non tunai, berdasarkan hasil wawancara yang telah penulis lakukan dengan para pihak yang melakukan akad, bahwa lafaz yang digunakan dalam pada saat berlangsungnya akad oleh masyarakat setempat adalah sebagai berikut:

"Iyya'pa tanggungngi semmeng duwa $s a^{, ", 12}$

\section{"Iyya' dui' limarratu' sabbu"13}

Akad perjanjian tersebut serupa dengan akad perjanjian hutang piutang yang dibolehkan dengan persyaratan apabila tidak bertentangan dengan ketentuan-ketentuan sak"

${ }^{12}$ Saya yang akan menanggung semen 2

${ }^{13}$ Saya yang menanggung 500 ribu" hukum Islam. ${ }^{38}$ Syarat-syarat tersebut menjadi sah apabila memenuhi:

1. Tidak menyalahi hukum syari'ah yang disepakati adanya.

2. Harus sama ridha dan ada pilihan.

3. Harus jelas dan gamblang. ${ }^{39}$

Zahrī Hamid memberi batasan akad lebih jelas dan terperinci, sebagai berikut:

"Akad atau perikatan ialah suatu ikatan antara dua pihak atau lebih tentang suatu urusan tertentu yang di mulai dengan kehendak salah satu pihak kemudian disetujui oleh pihak lain sehingga merupakan kesepakatan semua pihak yang bersangkutan dan mereka terikat karenanya. ${ }^{14}$

Dengan demikian akad sumbangan non tunai yang sifatnya utang yang terjadi pada pembangunan Masjid Baiturrahim Kab. Pinrang tentunya terdapat syarat-syarat, dimana dalam utang sumbangan tersebut harus dilunasi dalam jangka waktu tertentu. Akad perjanjian sumbangan utang yang awalnya hanya berbentuk pengakuan tersebut tertulis meskipun tidak ada saksi yang secara khusus dihadirkan oleh kedua belah pihak, namun perjanjian tersebut tetap mengikat karena kedua belah pihak telah sepakat dalam membuat akad atau perjanjian. Sesuai dengan perintah Allah yang tersurat dalam alBaqarah/2: 282

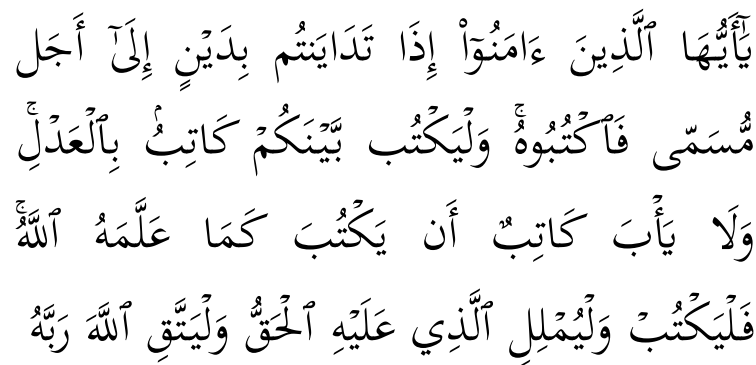

Terjemahnya:

Hai orang-orang yang beriman, apabila kamu bermu'amalah tidak secara tunai untuk waktu yang ditentukan, hendaklah kamu menuliskannya. Dan hendaklah seorang penulis di antara kamu

${ }^{14}$ Zahri Hamid, Asas-asas Mu'amalat Tentang Fungsi Akad dalam Masyarakat (Yogyakarta: IAIN Sunan Kalijaga, t. t), 13.

\section{9 | B a l a n c a}

Jurnal Ekonomi dan Bisnis Islam

Volume 2 Nomor 1, Januari - Juni 2020 (15 - 23) 
menuliskannya dengan benar. Dan janganlah penulis enggan menuliskannya sebagaimana Allah mengajarkannya, meka hendaklah ia menulis, dan hendaklah orang yang berhutang itu mengimlakkan (apa yang akan ditulis itu), dan hendaklah ia bertakwa kepada Allah Tuhannya. ${ }^{15}$

Para tokoh agama setempat juga mengemukakan bahwa tidak masalah jika hal ini disetujui oleh kedua belah pihak, bahwa hutang sumbangan akan dibayar dengan barang atau uang atas persetujuan kedua belah pihak. Total hasil sumbangan yang berhasil dipungut oleh panitia pembangunan mencapai tiga kali lipat dari sumbangan Bulan Ramadhan sebelumnya. Ditambah sumbangan yang berupa barang dirasakan sangat membantu dalam menyelesaikan pembangunan masjid. Menurut keterangan panitia pembangunan masjid, masyarakat sangat antusias dengan adanya sistem pelelangan sumbangan tersebut dibandingkan dengan sistem pemungutan sumbangan secara tunai.

Sumbangan non tunai yang dimaksud dalam penelitian ini adalah sumbangan yang sifatnya utang berupa pengakuan akan sumbangan pada pembangunan Masjid Baiturrahim di Dusun Sempang. Utang sumbangan tersebut ada setelah terjadinya akad/ perjanjian antara dua belah pihak yaitu pihak panitia masjid (pihak yang berpiutang) dan pihak masyarakat yang ingin menyumbang (pihak yang berutang), untuk melakukan transaksi hutang yang berupa sumbangan baik itu uang maupun barang dengan maksud akan melunasi utang tersebut di kemudian hari sesuai dengan syarat-syarat dan jangka waktu yang telah disepakati kedua belah pihak.

Dari perjanjian tersebut secara tersirat dapat diketahui bahwa masalah utang piutang sangatlah berhubungan dengan faktor keuangan dimana pihak yang berutang tersebut berada dalam kondisi berkekurangan

${ }^{15}$ Kementerian Agama RI, Mushaf AlQur'an Terjemah, 48. dalam hal keuangan. Seseorang akan secara terpaksa berutang apabila terjadi kesenjangan antara penghasilan yang diperoleh dengan jumlah pengeluaran yang digunakan. Oleh karena itu, utang piutang merupakan salah satu bentuk transaksi yang sering dilakukan oleh manusia dan ini berlaku pada seluruh jenis tingkatan masyarakat manusia baik pada masyarakat tradisional maupun masyarakat modern, maka dapat diperkirakan bahwa transaksi utang piutang merupakan transaksi yang telah dikenal sejak manusia ada di muka bumi ini ketika mereka mulai berinteraksi satu sama lain.

Utang piutang adalah memberikan sesuatu kepada seseorang dengan konsekuensi dia akan membayar yang sama pula. ${ }^{16}$ Dalam kasus yang menjadi topik dalam penelitian ini, sesuatu yang diberikan pihak yang berutang yang dimaksud adalah sebuah janji atau pengakuan. Hal ini sehubungan dengan hadis Nabi saw.

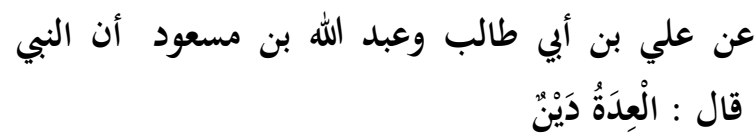

Artinya:

"Dari 'Ali bin Abi Thalib dan 'Abdullah bin Mas'ud, bahwa Rasulullah bersabda: "Janji adalah utang"

Hadis ini dikeluarkan oleh Imam atTabrani dalam al-Mu'jamul Ausat dan alMu'jamus shagir dan dinilai sebagai hadis yang lemah karena dalam sanadnya ada rawi yang bernama 'Abdullah bin Muhammad bin Abil Asy'ats. Sedangkan Imam adz-Dzahabi berkata tentangnya: "Dia meriwayatkan hadits yang mungkar, aku tidak mengenalnya". Ucapan beliau ini dibenarkan oleh Imam Ibnu Hajar. Imam al-'Iraqi dan Imam Ibnu Rajab juga mengisyaratkan kelemahan hadits ini, beliau berkata: "Di dalam sanadnya ada rawi yang tidak dikenal".

${ }^{16}$ Chairuman P. dan Suhrawardi KL. Hukum Perjanjian dalam Islam (Jakarta : Sinar Grafika, 1994), 136.

\section{0| B a l a n c a}

Jurnal Ekonomi dan Bisnis Islam

Volume 2 Nomor 1, Januari - Juni 2020 (15 - 23) 
Hadis ini juga dinyatakan lemah oleh Imam al-Haitsami, al-Munawi dan Syaikh al-Albani.

Kesimpulannya, hadis ini adalah hadis lemah sehingga tidak boleh dinisbahkan kepada Rasulullah saw. serta tidak boleh dijadikan sebagai argumentasi untuk menetapkan bahwa janji kedudukannya dalam Islam seperti utang. Namun meskipun hadis ini lemah, namun diperkuat dengan ayat-ayat al-Qur'an dan hadis-hadis sahih dari Rasulullah saw. yang sudah lebih dari cukup untuk dijadikan sandaran dan argumentasi tentang kewajiban menepati janji dan haramnya mengingkarinya.

Seperti firman Allah swt.:

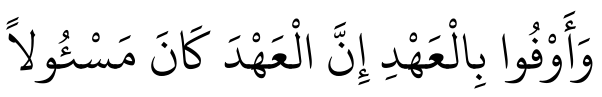

Terjemahnya:

"Dan penuhilah janji; sesungguhnya janji itu pasti diminta pertanggungjawabannya. ${ }^{17}$

Bukanlah merupakan suatu persoalan apabila utang piutang tersebut berupa barang atau pun uang. Islam membolehkan utang piutang yang sesuai syari'at Islam atau tidak bertentangan dengan al-Qur'an maupun alSunnah, termasuk utang yang berupa sumbangan yang ditunaikan para warga masyarakat apalagi demi pembangunan masjid. Namun yang menjadi masalah adalah ketika sumbangan yang dipungut melalui proses yang hampir mirip dengan pelelangan tersebut bergeser dari hakikatnya, yaitu dari pemberian dengan hati yang tulus atau sering disebut ikhlas menjadi pemberian yang menjadi beban masyarakat atau bahkan menimbulkan riya. Tidak ada yang bisa menjamin hati si penyumbang apakah benarbenar tulus atau hanya terbebani dengan "apa kata tetangga" karena proses pemungutan dilakukan di depan khalayak.

Padahal Rasulullah saw. telah bersabda

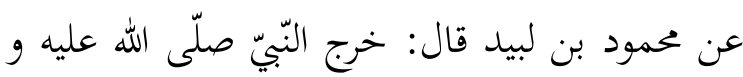

${ }^{17}$ Kementrian Agama RI, Mushab al-Quran Terjemah, h. 285.
سلّم فقال : ايّها النّاس! ايّّكم والشّرك السّرائر ! قالوا: يارسول الله وما شرك السّرائر. قال يقوم الرّجل فيصلّى لِّل فيزيّن صلاته جاهدا لما يرى من نظر النّاس اليه فدالك رك

$$
\text { شرك السّرائر. (رواه ابن حزيمة) }
$$

Artinya:

"Dari Mahmud bin Labid, ia berkata: Nabi saw keluar seraya bersabda "Wahai manusia, jahuilah oleh kalian syirik yang tersembunyi...!" Mereka bertanya: Wahai Rasulullah, apakah itu syirik yang tersembunyi?" Nabi bersabda: "Seorang berdiri mengerjakan shalat, lalu membagusi shalatnya dengan sungguh-sungguh karena ia melihat perhatian orang terhadap dirinya, maka itulah syirik yang tersembunyi" (HR. Ibnu Huzaimah). ${ }^{18}$

Riya adalah sikap atau perilaku yang ada di dalam hati manusia yang mendorong keinginan dirinya untuk memperlihatkan amal-amal yang dilakukannya kepada orang lain dengan tujuan untuk mendapatkan pujian atas apa yang diperbuatnya. Lawan kata dari riya adalah ikhlas, artinya segala sesuatu yang dilakukan seseorang, baik dari segi perbuatan lahiriyah maupun jasmaniah dilakukan dengan tanpa terbetik sedikitpun adanya riya di hati, dengan kata lain hanya mengharapkan ridla Allah semata tanpa mengharapkan imbalan dari selain Allah. Dalam kitab AlHikam, Ibnu Atho'illah menyatakan bahwa ikhlas adalah ruh dari amal, dan jasmaniahnya amal perbuatan adalah tindakan nyata. Amal ibadah yang kuat tegaknya dan kokoh ikatannya dengan iman hanya ada dalam hati yang ikhlas. Dan amal yang ikhlas menunjukan tegaknya iman. ${ }^{19}$

${ }^{18} \mathrm{Al}$ Hafidz Syihabbuddin Ahmad bin Ali bin Hajar Al Asqolani, Ringkasan Targhib wa Tarbib, (Pustaka Azzam : Jakarta, 2006), 6.

${ }^{19}$ As-Syeikh Ibnu Atho'illah As Sakandary, Mutu Manikam dari Kitab Al Hikam, (Mutiara Ilmu : Surabaya, 2012), 35.

\section{B a l a n c a}


Masalah selanjutnya adalah pemungutan sumbangan yang dilakukan dalam bulan Ramadhan seakan memanfaatkan momen karena bulan Ramadhan adalah bulan dimana manusia berlomba-lomba melipat-gandakan amal ibadahnya. Psikologi masyarakat yang pada bulan ramadhan memiliki spirit spiritual yang meninggi secara otomatis semakin bergejolak dengan iming-iming lipatan pahala tadi. Mereka akan segera aktif merespon dengan memberikan semaksimal mungkin apa yang bisa mereka berikan. Secara sepintas memang tidak ada yang salah, tapi jika ditelusuri secara mendalam maka akan ditemukan kenyataan bahwa niat masyarakat yang seharusnya menyumbang demi kemaslahatan melalui pembangunan dan pemakmuran masjid justru akan berubah bak pemburu pahala semata.

Di sisi lain keberadaan utang sumbangan ini dapat dikatakan sebagai transaksi yang secara kasat mata bersifat sukarela, namun terdapat nilai komersialnya. Panitia pembangunan masjid sebagai pihak yang berpiutang atau dalam hal ini pemungut sumbangan kelihatannya meminta berdasarkan ketulusan hati si pemberi sumbangan. Namun jika diperhatikan lafadznya, seperti

"Nasaba melo'i ribangun masigita, assumbakki semmeng cenning-cenning atitta, siddi, dua sak gi tasumbang sesuai semmeng lesepakatie pole mega lebbih pi kanja'na idi sendiri ga melli semmena atau dui' ta sumbangeng letarima maneng" 20

Justru terkesan memberi batasan sumbangan yang harus dikeluarkan oleh masyarakat padahal subtansi dari sumbangan itu tidak lain adalah cenning-cenning ati. ${ }^{21}$

${ }^{20}$ Dalam rangka pembangunan masjid kita, menyumbanglah semen setulus hati, apakah itu satu atau dua sak. Apabila lebih banyak maka lebih bagus, baik itu pribadi sendiri yang mau membeli semen atau menyumbang berupa uang juga tidak masalah.

${ }^{21}$ Berapapun asalkan setulus hati
Dalam perjanjian sumbangan utang yang terjadi di dusun Sempang hingga saat skripsi ini disusun belum ada konflik yang terjadi antara pihak yang berutang dan berpiutang karena mereka menggunakan asas kekeluargaan. Jadi kalau misalnya masyarakat yang berutang melakukan wanprestasi (ingkar janji) dalam hal belum dapat melunasi utangnya, maka kedua pihak akan menyelesaikannya dengan cara kekeluargaan.

Untuk mengetahui bagaimana hukum sumbangan non tunai dalam fiqhi ekonomi, penulis merujuk pada metode maslahah mursalah dalam maqasid syariah. Sebab banyak persoalan baru bisa dikategorikan sebagai lahan maslahah mursalah. Artinya persoalan baru itu memang mengandung maslahat dan dibutuhkan manusia dalam membangun kehidupan mereka, tetapi tidak ditemukan dalil yang mengakui ataupun menolaknya.

Maslahah mursalah merupakan salah satu metode ijtihad yang menjadikan hukum Islam dapat lebih dinamis dan bersifat kontekstual, serta tidak ketinggalan zaman, karena perkara-perkara yang baru dan belum ada ketentuan hukumnya dalam al-Qur'an dan asSunnah dapat ditentukan hukumnya dengan jalan ijtihad yang salah satunya menggunakan metode maslahah mursalah. Masalah-masalah lama yang ditentukan hukumnya dengan jalan ijtihad tetapi tidak relevan/ berlaku lagi secara efektif dalam masyarakat, karena perkembangan zaman sudah berlainan, maka terhadap masalah-masalah lama tersebut dapat ditentukan atau diubah ketentuan hukumnya sesuai dengan zamannya dengan dasar pertimbangan yang lebih manfaat dan maslahat sepanjang dibenarkan syara'. Namun unutk menjaga kemurnian maslahah mursalah sebagai landasan hukum Islam, maka harus memperhatihan dua dimensi penting yaitu; Pertama Harus tunduk dan sesuai dengan apa yang terkandung dalam nash, baik secara tekstual maupun kontekstual. Kedua Harus mempertimbangkan

\section{2 $\quad$ B a l a n c a}


adanya kebutuhan manusia yang selalu berkembang sesuai zamannya.

Dalam kasus sumbangan non tunai pada pembangunan Masjid Baiturrahim, tidak dijumpai nash yang menunjukkan langsung pada hukum masalah. al-Qur'ân dan alSunnah tidak pernah menjelaskan secara gamblang tentang perintah untuk menyumbang atau dalam bahasa penulis "infaq non-tunai". Islam hanya mensyariatkan sumbangan dengan istilah zakat, infaq dan shadaqah bagi orang-orang yang mampu dan tidak pernah memerintahkan seseorang menginfakkan harta yang bahkan belum pasti dimilikinya. Tetapi hal ini menjadi kebutuhan penting bagi pembangunan masjid di Dusun Sempang Timur Kec. Patampanua Kab. Pinrang. Pembangunan masjid tersebut membutuhkan inovasi dan kreativitas panitianya demi kelancaran pembangunan sehingga dapat mewujudkan fungsi masjid sebagai baitulla\}h, tempat beribadah masyarakat serta memberi keamanan dan kenyamanan kepada masyarakat dalam menjalankan ibadahnya. Oleh karena itu pemungutan sumbangan non tunai boleh dilakukan asalkan tidak menggunakan unsur paksaan

\section{Kesimpulan}

Berdasarkan pengkajian yang mendalam tentang permasalahan penelitian maka penulis menyimpulkan bahwa;

Yang Pertama, pelaksanaan akad sumbangan non tunai atau sumbangan yang sifatnya utang tidak melanggar aturan-aturan yang dimuat dalam hukum Islam, karena dalam akadnya para pihak sama-sama mencapai kata sepakat. Akad justru sangat disyaratkan dalam pelaksanaan sumbangan ini agar antara si penyumbang dan yang menerima sumbangan tidak ada yang saling menzalimi serta tidak ada pihak yang dirugikan.

Yang Kedua, sistem pemungutan sumbangan non tunai untuk pembangunan
Masjid Baiturrahim dilakukan secara berkala. Dalam proses pemungutan sumbangan, panitia pembangunan melakukan pelelangan dengan cara menawarkan dan meminta kerelaan masyarakat yang ingin menyumbang untuk memenuhi segala kebutuhan masjid baik itu berupa bahan bangunan maupun fasilitas pelengkap untuk memberi rasa nyaman kepada warga yang melaksanakan ibadah.

Yang Ketiga, seiring dengan perjalanan waktu, persoalan-persoalan baru yang tidak ada ketentuannya dalam nash akan terus berlangsung sepanjang masa dengan berbagai perbedaan latar belakang sosial budaya. Dengan demikian, untuk mengatasi persoalan-persoalan tersebut, tidak lain melalui metode ijtihad yang salah satunya adalah maslahah mursalah. Mengingat banyaknya maslahah yang didatangkan sumbangan non tunai ini, penulis menyimpulkan bahwa hukum sumbangan non tunai pada dasarnya adalah boleh dengan catatan tidak mengandung unsur paksaan dan riya di dalamnya serta peruntukannya bukan ke hal-hal yang sifatnya duniawi melainkan untuk melaksanakan tugas utama sebagai khalifah di bumi yaitu beribadah di jalan Allah swt.

\section{Daftar Pustaka}

Al Asqolani, Al Hafidz Syihabbuddin Ahmad bin Ali bin Hajar Ringkasan Targhib wa Tarhib, Pustaka Azzam : Jakarta, 2006.

al-Ba'labakiyy, Munir. Qamus al-Mawrid. Beirut: Dar al-'Ilm al-Malayyin, 1990.

Arifin, Gus. Dalil-dalil dan Keutamaan Zakat, Infak, Sedekah, Jakarta: Elex Media Komputindo, 2011.

Echols, John M. dan Hassan Shadily, Kamus Inggris-Indonesia (cet. XXIII, Jakarta: Gramedia Pustaka, 1996.

Fawari. Tinjauan Hukum Islam Terhadap Sumbangan dalam Hajatan pada

\section{B a l a n c a}


Pelaksanaan Walimah dalam

Perkawinan di Desa Rima Balai Kec. Banyuasin III Kab. Banyuasin Sumatera Selatan, Yogyakarta: Universitas Islam Negeri Sunan Kalijaga, 2010.

Hamid, Zahri. Asas-asas Mu'amalat Tentang Fungsi Akad dalam Departemen Agama RI. Al-Qayyum Al-Qur'an dan Terjemahannya Disertai Transliterasi. Semarang: PT. Karya Toha Putra

Dikutip dari Lexy J. Moleong. 2007. Metodologi Penelitian Kualitatif. Bandung: Remaja Rosdakarya 